\title{
Vaccine-associated systemic Rhodococcus erythropolis infection in farmed Atlantic salmon Salmo salar
}

\author{
A. B. Olsen ${ }^{1, *}$, T. H. Birkbeck ${ }^{2}$, H. K. Nilsen ${ }^{1}$, H. L. MacPherson ${ }^{2}$, C. Wangel $^{3}$, \\ C. Myklebust ${ }^{4}$, L. A. Laidler ${ }^{5}$, L. Aarflot ${ }^{6}$, E. Thoen $^{7,8}{ }^{\text {, S. Nygård }}{ }^{9}$, \\ T. Thayumanavan ${ }^{8,10}$, D. J. Colquhoun ${ }^{8}$ \\ ${ }^{1}$ National Veterinary Institute Bergen, PO Box 1263 Sentrum, 5811 Bergen, Norway \\ ${ }^{2}$ Division of Infection and Immunity, Joseph Black Building, University of Glasgow, Glasgow G12 8QQ, UK \\ ${ }^{3} 5993$ Ostereidet, Norway \\ ${ }^{4}$ Fjord-Lab AS, PO Box 7, 6701 Måløy, Norway \\ ${ }^{5}$ Marine Harvest McConnell, Lochailort, Inverness-shire PH38 4LZ, UK \\ ${ }^{6}$ Nordvest Fiskehelse, Dragsund, 6080 Gurskøy, Norway \\ ${ }^{7}$ VESO Vikan AkvaVet, Vikan, 7800 Namsos, Norway \\ ${ }^{8}$ National Veterinary Institute, PO Box 8156 Dep, 0033 Oslo, Norway \\ ${ }^{9}$ Fiskehelse og Miljø AS, Ramsvollsv. 1, 5518 Haugesund, Norway \\ ${ }^{10}$ Department of Environmental Sciences, Bharathiar University, Coimbatore 641046, India
}

\begin{abstract}
In 7 instances between 2000 and 2003, clinical investigation of populations of fresh- and seawater-reared, vaccinated, Atlantic salmon Salmo salar suffering total losses of between 0.1 and $35 \%$ revealed infection with a Gram-positive rod-shaped bacterium. The isolations were geographically widespread, occurring in both Norway and Scotland. In all cases, a Gram-positive bacterium, subsequently identified as Rhodococcus erythropolis, was isolated in pure culture. Infections, although systemic, were focused within the peritoneal cavity. While initial attempts to reproduce the disease by intraperitoneal injection of unvaccinated Atlantic salmon failed, Koch's postulates were subsequently fulfilled in fish vaccinated with a commercially available oil-adjuvanted vaccine.
\end{abstract}

KEY WORDS: Rhodococcus erythropolis · Vaccination · Atlantic salmon · Salmo salar · Disease · Pathology $\cdot$ Peritonitis

Resale or republication not permitted without written consent of the publisher

\section{INTRODUCTION}

Bacterial infections in fish occur as the result of the interaction between host, pathogen and environment (Austin \& Austin 1999), and the contribution of the farming environment towards development of disease cannot be overestimated. Thus, several bacterial fishpathogens, e.g. Vibrio salmonicida and Moritella viscosa, have, to the best of our knowledge, never been identified in wild fish. Gram-positive bacteria represent a relatively small proportion of bacteria isolated from diseased farmed salmonids in the Northern hemi- sphere, and despite the increasing worldwide scrutiny of pathogens of farmed fish, serious disease due to Gram-positive bacteria (with the exception of Renibacterium salmoninarum) has so far been mainly limited to fish reared in warmer waters. In this paper we report on the isolation of the Gram-positive bacterium Rhodococcus erythropolis from several disease outbreaks involving vaccinated farmed Atlantic salmon. Evidence is presented which directly links the disease to the aquaculture process. Epidemiology, pathology, bacteriology, as well as transmission experiments are presented. 


\section{MATERIALS AND METHODS}

Fish. Moribund fish from all 7 disease outbreaks (see Table 1) were sampled for pathological and bacteriological examination.

Histopathology. Gills, heart, liver, kidney, spleen, pancreatic tissue, skeletal musculature and occasionally brain were sampled for histopathology. The samples were fixed in $4 \%$ neutral buffered formalin, embedded in paraffin wax and routinely processed. The sections were stained by haematoxylin and eosin (H\&E). A selected number of slides were also stained using Gram and May Grünwald Giemsa stains.

Bacteriology. For bacteriological examination, samples from kidney and in some cases ascitic fluid, were inoculated onto blood agar (BA, $4 \%$ bovine or equine blood ) and blood agar supplemented with $1.5 \% \mathrm{NaCl}$ (BAS) followed by aerobic incubation at 22 and $15^{\circ} \mathrm{C}$, respectively. Plates were observed for $7 \mathrm{~d}$. Bacterial isolates were subsequently stored at $-80^{\circ} \mathrm{C}$.

Biochemical characterisation. Basic biochemical characterisation was performed using standard methods. Each strain was also tested using BIOLOG (Hayward) and API $20 \mathrm{NE}$ (Biomerieux) kits according to the manufacturers' instructions. The ability of each strain to assimilate various carbon sources was examined by inoculating API $50 \mathrm{CH}$ kits (Biomerieux) with bacteria suspended in a medium comprising $1.5 \mathrm{~g}$ agar, $2.0 \mathrm{~g}$ ammonium sulphate, $0.25 \mathrm{~g}$ Casamino acids (Difco) and $1 \mathrm{ml}$ trace element solution.

DNA sequencing. The $16 \mathrm{~S}$ rRNA gene of Strains 00/50/6670 and 4115 were amplified using PCR and primers FD1 and RP2 (Weisburg et al. 1991). DNA sequencing was performed using the BigDye ${ }^{\mathrm{TM}}$ terminator cycle sequencing ready reaction kit (PE Applied Biosystems) and an automatic ABI prism 377 sequencer (Perkin Elmer). Sequence analysis was performed using the sequencer program (Gene Codes) and BLAST search analysis (Altschul et al. 1997).

Phylogenetic analysis. Sequences were aligned using CLUSTAL W (Thompson et al. 1994). A neighbour-joining tree based on Kimura 2-parameter distances was calculated using PAUP* 4.0 (Swofford 2000). The tree was bootstrapped 1000 times to assess node reliability.

Enterobacterial repetitive intergenic consensus PCR (ERIC-PCR). ERIC-PCR was performed using the forward primer $5^{\prime}$-atg taa gct cct ggg gat tca c-3' and reverse primer $5^{\prime}$-aag taa gtg act ggg gtg agc g-3' (Ventura \& Zink 2002). Each $50 \mu \mathrm{l}$ reaction mixture contained $5 \mu \mathrm{l} 10 \times$ reaction buffer (Roche), $200 \mu \mathrm{M}$ of each deoxynucleoside triphosphates (Invitrogen), 25 pmol of each primer (Invitrogen), 2 U Taq polymerase (Roche) and $20 \mathrm{ng}$ of the respective DNA template. Samples were denatured at $94^{\circ} \mathrm{C}$ for $3 \mathrm{~min}$ followed by 35 cycles of: $94^{\circ} \mathrm{C} \times 30 \mathrm{~s}, 50^{\circ} \mathrm{C} \times 60 \mathrm{~s}$ and $72^{\circ} \mathrm{C} \times 5 \mathrm{~min}$, followed by 1 cycle of $72^{\circ} \mathrm{C}$ for $5 \mathrm{~min}$. ERIC products were separated by electrophoresis in a $1 \%(\mathrm{w} / \mathrm{v})$ agarose gel at a constant voltage of $2 \mathrm{~V}$ $\mathrm{cm}^{-1}$. PCR patterns were stained with ethidium bromide $\left(0.5 \mu \mathrm{g} \mathrm{ml}^{-1}\right)$ and visualised under UV light at $254 \mathrm{~nm}$.

Production of antisera and slide-agglutination. Antiserum against Strain 00/50/6670 was raised in a chinchilla rabbit according to the protocol of Larsen et al. (1994). Isolates representing all known outbreaks of disease were tested with this antiserum. Following incubation on BA plates at $22^{\circ} \mathrm{C}$ for $48 \mathrm{~h}$, the test bacteria were suspended in sodium acetate-buffered saline $(0.05 \mathrm{M} \mathrm{NaAc}, 0.1 \mathrm{M} \mathrm{NaCl}, 1 \%[\mathrm{v} / \mathrm{v}]$ formalin $\mathrm{pH}$ 7.5). Equal volumes $(10 \mu \mathrm{l})$ of bacterial suspension and antiserum were mixed and agitated. Reactions were considered positive if agglutination of bacteria occurred within $30 \mathrm{~s}$.

Infection challenges. Small-scale infectious challenges on salmon pre-smolts (approximate weight $50 \mathrm{~g}$ ) were performed at water temperatures of 4.5 and $14.5^{\circ} \mathrm{C}$, respectively. The challenge bacterium (00/50/6670) used was isolated in Hordaland County (Norway) during 2000. In the first challenge, 3 groups of 5 fish were injected intra-peritoneally with $100 \mu \mathrm{l}$ saline containing $2 \times 10^{5}, 2 \times 10^{7}$ or $2 \times 10^{8}$ bacteria. In addition, 1 group of 5 fish was injected with $100 \mu \mathrm{l}$ saline. In the second challenge, 3 fish were injected with $2 \times 10^{7}$ bacteria, 3 fish with $2 \times 10^{4}$ bacteria and 4 fish were uninjected cohabitants. In both experiments all groups were held in a single tank (100 l). The fish were fed to satiation and monitored daily for mortalities. The surviving fish were sacrificed $3 \mathrm{wk}$ postchallenge and submitted to bacteriological examination, and samples were taken for histology.

Following taxonomic placement of the bacterium, a third infection trial was designed and performed. The experiment utilised 56 Atlantic salmon smolts of approximately $60 \mathrm{~g}$, individually marked and held in full strength seawater (34.5\%) in a single tank of $200 \mathrm{l}$. The fish were divided into 5 groups, sedated, marked and treated as follows: Fish in Group A were injected intraperitoneally with $2 \times 10^{7}$ cfu Rhodococcus erythropolis in $0.1 \mathrm{ml}$ phosphate-buffered saline (PBS), Group B received 2 separate injections of $2 \times 10^{7} \mathrm{cfu} R$. erythropolis in $0.1 \mathrm{ml}$ PBS $+0.1 \mathrm{ml}$ vaccine (multivalent, oil-adjuvanted), Group $\mathrm{C}$ received a single injection of $2 \times 10^{7}$ cfu $R$. erythropolis in $0.1 \mathrm{ml}$ PBS $+0.1 \mathrm{ml}$ vaccine. Control Groups D and E received $0.1 \mathrm{ml}$ vaccine and $0.1 \mathrm{ml} \mathrm{PBS}$, respectively. The vaccine used was of the same type, but of a different batch, to that used prior to 2 of the field outbreaks, and was kindly provided by the manufacturer. The vaccination/challenge was initiated $1 \mathrm{wk}$ following exposure of the fish to full 
strength seawater. The water temperature was raised on the day of the challenge from 9 to $12^{\circ} \mathrm{C}$, and was maintained at that level for the remainder of the trial.

Fifteen fish, scattered among Groups B to E, did not recover from the initial sedation, and the experimental population was thereby reduced to 41 individuals (11 fish in Group A, 5 in Group B, 9 in Group C, 9 in Group D and 7 in Group E). Dead fish were removed daily for the duration of the experiment, which lasted for $45 \mathrm{~d}$. Post-mortem examination and routine bacteriology from kidney and occasionally ascitic fluid was performed on all fish that died and on surviving fish sacrificed at the end of the experiment.

\section{RESULTS}

\section{Epidemiology}

The cases reported comprised 2 cases in Scotland and 5 cases in Norway, in farmed Atlantic salmon (Table 1). Mortality levels in the Scottish farms involved were lower than those in the Norwegian farms, where reported cumulative mortalities ranged between 1.3 and $35 \%$ in affected populations. In Norway the first detection was in post-smolts 1 mo following sea transfer (Olsen et al. 2001), and all other cases were diagnosed prior to sea transfer. One of the 5 Norwegian cases occurred (unforeseen) in fish under experimental conditions. Onset of infection occurred at high as well as at low water temperatures.

Affected farms in both countries were widely separated geographically. All cases occurred in fish intraperitoneally vaccinated in the freshwater phase with either monovalent (Scotland) or multivalent (Nor- way) oil-adjuvanted vaccines (Table 1), produced by more than 1 vaccine manufacturer.

\section{Gross pathology}

Moribund fish suffered from scale loss and, occasionally, cutaneous haemorrhage of the abdomen and the bases of the pectoral and abdominal fins were observed; some fish showed distention of the abdomen (Fig. 1). Bilateral exophthalmia was reported in the Scottish cases. Internal findings, including splenomegaly, petechiation of parietal peritoneum and serous to serohaemorrhagic ascites, were consistent with a systemic infection. A typical finding was severe peritonitis, visible as a whitish, loose to compact pseudo-membrane, in some cases containing small fluid- or 'pus'-filled cavities, covering internal organs. Vaccine-related peritoneal adhesions were common in all fish and the stomach had a seromucoid content.

\section{Histopathology}

Histopathology revealed the presence of Grampositive, rod-shaped bacteria (Figs. 3 to 6), with the bacteria being especially numerous in association with subacute to chronic vaccine-related peritonitis (Figs. 3, 5 \& 6). Aggregates of bacteria and accompanying inflammatory reaction were also observed subepicardially, and occasionally in skeletal musculature. Bacterial colonies were found intravascularly in different organs (Fig. 4) and as intra-luminal thrombi in the spongy myocardium. Diseased fish usually displayed leucocytosis.

Table 1. Salmo salar. Known outbreaks of infection with Rhodococcus erythropolis in farmed Atlantic salmon. Age/wt: age of fish and weight at time of diagnosis; Diagnosis time: time from vaccination to diagnosis of disease; Mortal.: cumulative mortality; $T$ : temperature at time of vaccination; N: Norway; S: Scotland; fw: freshwater; br: brackish water; sw: seawater; na: no isolate available; nd: no data

\begin{tabular}{|c|c|c|c|c|c|c|c|c|}
\hline \multirow[t]{2}{*}{ Outbreak } & \multirow{2}{*}{$\begin{array}{l}\text { Bacterial } \\
\text { isolate }\end{array}$} & \multirow{2}{*}{ Age/wt } & \multirow{2}{*}{ Water } & \multicolumn{2}{|c|}{ Diagnosis } & \multirow{2}{*}{$\begin{array}{c}\text { Mortal. } \\
(\%)\end{array}$} & \multirow{2}{*}{$\begin{array}{c}T \\
\left({ }^{\circ} \mathrm{C}\right)\end{array}$} & \multirow[t]{2}{*}{ Vaccine } \\
\hline & & & & Date & Time & & & \\
\hline N-1 & $00 / 50 / 6670$ & Smolt/150 g & sw & Nov 2000 & $3 \mathrm{mo}$ & $23^{\mathrm{a}}$ & nd & $\mathrm{A}^{\mathrm{c}}$ \\
\hline N-2 & $02 / 50 / 2284$ & Parr/50 g & $\mathrm{fw} / \mathrm{br}$ & Aug 2002 & $14 \mathrm{~d}$ & 11 & $18-20$ & $\mathrm{~A}$ \\
\hline N-3 & $03 / 50 / 822$ & Smolt/70 g & fw & Feb 2003 & $3 \mathrm{mo}$ & 1.3 & $1.8-3$ & $\mathrm{~B}^{\mathrm{d}}$ \\
\hline $\mathrm{N}-4$ & 03/09/159 & Smolt/70 g & fw & Dec 2002 & $17 \mathrm{~d}$ & $20-35^{b}$ & 12 & nd \\
\hline N-5 & 03/40/5697 & Smolt/80 g & fw & Mar 2003 & $4.5 \mathrm{mo}$ & 3 & 5 & B \\
\hline S-1 & na & Adult/1 kg & sw & Jul 2000 & $8 \mathrm{mo}$ & $<0.5$ & 6 & $\mathrm{C}^{\mathrm{e}}$ \\
\hline $\mathrm{S}-2$ & 4115 & Post-smolt/300 g & sw & Sep 2000 & $10 \mathrm{mo}$ & $<0.1$ & 6 & $\mathrm{C}$ \\
\hline \multicolumn{9}{|c|}{$\begin{array}{l}\text { a Also other disease problems, antibiotic treatment in February } 2001 \\
{ }^{b} \text { Mortality within } 2 \text { test groups of } 50 \text { individuals each in tank with total population of } 700 \text { fish } \\
\text { c Multivalent, oil-adjuvanted, } 5 \text { bacterial antigens } \\
{ }^{\mathrm{d}} \text { Multivalent, oil-adjuvanted, } 5 \text { bacterial antigens and } 1 \text { virus antigen } \\
\text { e Monovalent, oil-adjuvanted, } 1 \text { bacterial antigen }\end{array}$} \\
\hline
\end{tabular}



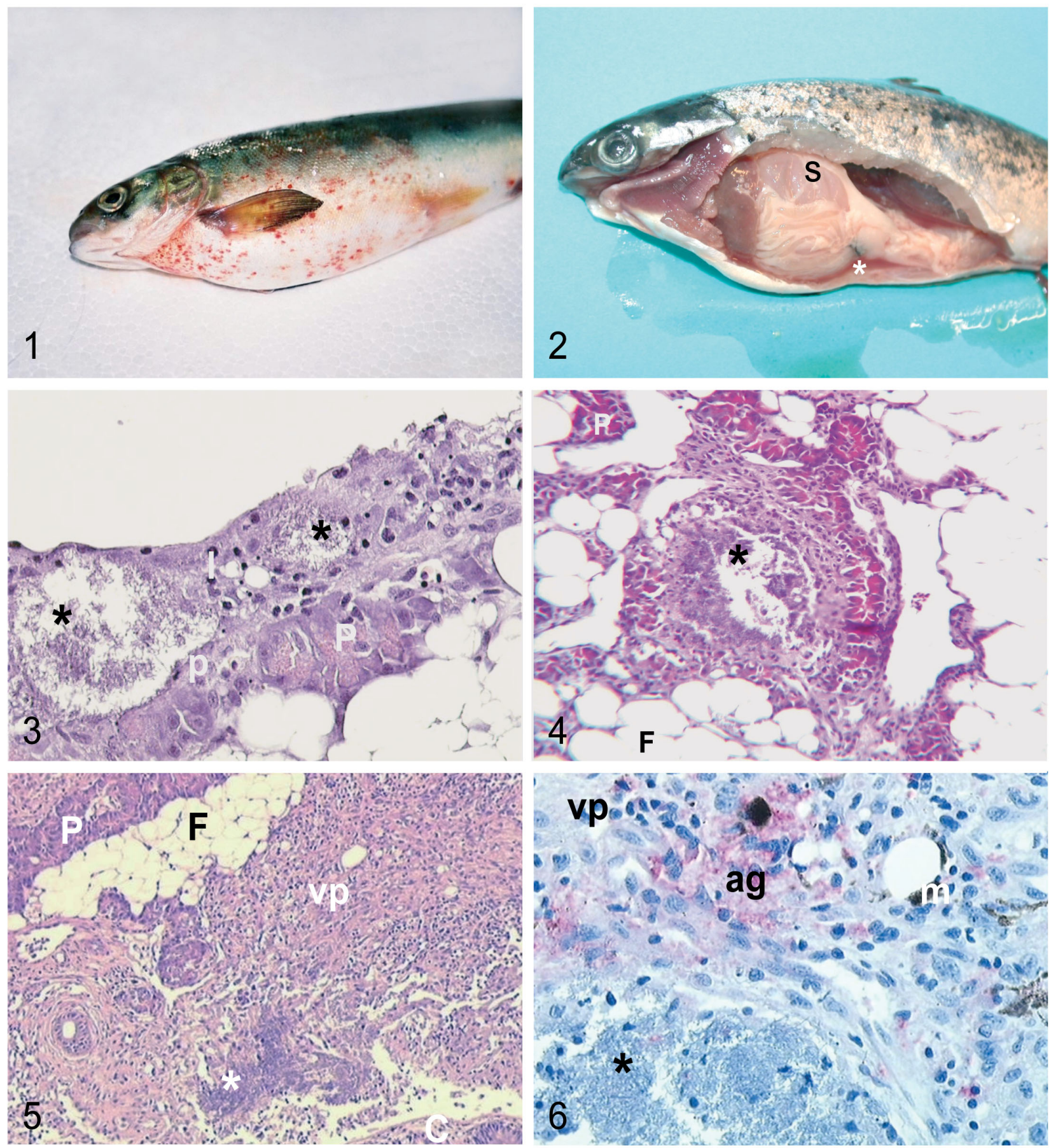

Fig. 1. Salmo salar. Parr naturally infected by Rhodococcus erythropolis, showing extensive haemorrhaging of skin and distended abdomen. Fig. 2. Salmo salar. Smolt from Infection Challenge 3, dead 9 d after intraperitoneal injection with both Rhodococcus erythropolis and oil-adjuvanted vaccine. Stomach is very distended (s), with seromucoid content. Serohaemorrhagic ascites present (*). Fig. 3. Salmo salar. Smolt naturally infected by Rhodococcus erythropolis. Peritonitis with numerous bacteria (*) and leucocytes (1). p: peritoneal lining; P: normal exocrine pancreas. Haematoxylin and eosin (H\&E) staining. Fig. 4. Salmo salar. Smolt naturally infected by Rhodococcus erythropolis. Bacteria within large vessel (*); F: perivisceral fatty tissue; P: exocrine pancreas. H\&E. Fig. 5. Salmo salar. Smolt naturally infected by Rhodococcus erythropolis. Chronic, vaccine-induced, granulomatous peritonitis (v). Pockets with aggregates of Rhodococcus erythropolis (*). F: perivisceral fatty tissue; P: exocrine pancreas; C: pyloric caeca. H\&E. Fig. 6. Salmo salar. Smolt naturally infected by Rhodococcus erythropolis. Chronic vaccine-induced peritonitis (vp) with infiltration of melanomacrophages (m). ag: Aeromonas salmonicida ss salmonicida antigen, a vaccine component, is stained red by immunohistochemistry. Large aggregate of $R$. erythropolis is visible adjacent to peritoneal reaction (*). H\&E. Original magnifications: (3) $\times 200,(4) \times 200,(5) \times 40,(6) \times 400$ 


\section{Bacteriology}

Phenotypic analysis

The bacteria described were isolated in pure culture or as the dominant colony type in mixed cultures from all fish examined. All isolates produced round, shiny, convex, beige and non-haemolytic colonies on BA. All isolates were strictly aerobic, Gram-positive rods, and were cytochrome oxidase negative and catalase positive. Growth rate was reduced with the addition of $1.5 \% \mathrm{NaCl}$ to the BA medium. The bacteria grew better at $30^{\circ} \mathrm{C}$ than at $15^{\circ} \mathrm{C}$, but there was no growth at 4 or $37^{\circ} \mathrm{C}$. Differences occurred in carbohydrate utilisation, as shown in Tables $2 \& 3$.

\section{Slide agglutination}

Positive agglutination was achieved with the isolate used for antiserum production (00/50/6670) and in 1 other isolate $(03 / 40 / 5697)$. Weak agglutination was observed with the type strain (NCIMB 11148). The remaining isolates gave negative results.

\section{Genotypic analysis}

Nearly complete $16 \mathrm{~S}$ rDNA sequences were obtained from 1 Norwegian and 1 Scottish isolate and these were submitted to Genbank under Accession Nos. AY147846 (00/50/6670) and AJ505559 (4115), respectively. Alignment of these sequences revealed significant homology $(99.8 \%)$ between the 2 sequences. BLAST searching revealed high degrees of similarity to the genus Rhodococcus, with identity levels of 100 and $99.9 \%$ for Norwegian and Scottish isolates, respectively, with $R$. erythropolis ATCC13260. The relationships between the strains are presented as a phylogenetic tree in Fig. 7.

\section{ERIC-PCR}

PCR amplification using ERIC I and ERIC II primers produced a distinctive fingerprint for each strain. While the 2 reference strains produced quite different profiles, common bands were identified in the Scottish isolate, several Norwegian isolates and Rhodococcus erythropolis Type Strain NCIMB 11148. No 2 isolates produced identical profiles (Fig. 8).

\section{Infectivity trial}

\section{Infection Challenges 1 and 2}

Fish began to feed on the day following injection of the bacteria; they appeared healthy and maintained good appetite throughout the remainder of the experimental period. No mortalities were recorded and no bacteria were isolated from the fish sacrificed at the end of the trials. No pathological changes were found following histological examination of formalin-fixed tissues.

\section{Infection Challenge 3}

With the exception of 2 individuals from the group receiving vaccine alone, mortality was confined to the 2 groups challenged with both bacteria and vaccine (Fig. 9). Heavy growth of the bacterium was achieved from kidney tissue in all dead fish and in the ascitic

Table 2. Isolate differences in carbohydrate utilisation using AP20NE and AP50CH. All isolates were positive for utilisation of glycerol, glucose, inositol, mannitol, sorbitol, N acetyl glucosamine, sucrose, trehalose, D-arabitol, adipate, malate, phenylacetate and gluconate; all isolates were negative for utilisation of D-arabinose, L-arabinose, D-xylose, L-xylose, $\beta$-methyl xyloside, galactose, D-mannose, L-sorbose, rhamnose, dulcitol, $\alpha$-methyl-D-mannoside, $\alpha$-methyl-D-glucoside, D-turanose, amygdalin, caprate, esculin, salicin, cellobiose, maltose, lactose, melibiose, inulin, melizitose, D-raffinose, starch, glycogen, $\beta$-gentibiose, D-lyxose, D-tagatose, D-fucose, L-fucose and 2 keto-gluconate

\begin{tabular}{|lccccccccc|}
\hline Substrate & NCIMB & ATCC & $00 / 50 / 6670$ & 4115 & $03 / 50 / 822$ & $03 / 40 / 5697$ & $03 / 09 / 159$ & $02 / 50 / 2284 \mathrm{a}$ & $02 / 50 / 2284 \mathrm{~b}$ \\
& 11148 & 13260 & & & & & & & \\
& & - & - & - & - & + & + & - & + \\
Erythritol & - & + & + & + & + & + & + & + & + \\
Ribose & - & - & - & - & + & + & - & - & + \\
Adonitol & - & - & + & - & - & - & - & - & + \\
Arbutin & + & + & - & + & - & - & - & + \\
Xylitol & - & - & - & - & + & + & - & + \\
L-arabitol & + & - & - & - & + & - & + & + \\
5 keto-gluconate & + & + & + & + & - & + & + & + \\
Citrate & + & + & + & + & - & + & + \\
\hline
\end{tabular}


Table 3. Isolate differences in carbohydrate utilisation using BIOLOG. All isolates were positive for utilisation of Tween 40, Tween 80, D-arabitol, D-fructose, D-mannitol, D-sorbitol, monomethyl succinate, acetic acid, D-gluconic acid, $\beta$-hydroxybutyric acid, propionic acid, quinic acid, sebacic acid, succinic acid, bromosuccinic acid, D-alanine, L-alanine, L-asparagine, L-leucine, L-phenylalanine, urocanic acid, putrescine, 2-aminoethanol and glycerol; all isolates were negative for utilisation of cyclodextrin, $\mathrm{N}$-acetyl-D-galactosamine, L-arabinose, L-fucose, D-galactose, gentobiose, $\alpha$-lactose, $\alpha$-D-lactose-lactulose, D-melibiose, $\beta$-methylD-glucoside, psicose, saccharic acid, succinamic acid, glucuronamide, L-glutamic acid, L-histidine, hydroxy-L-proline, L-ornithine, D-serine, D,L-carnitine, D-raffinose, L-rhamnose, sucrose, D-trehalose, turanose, xylitol, cis-aconitic acid, formic acid, D-galactonic acid lactone, D-galacturonic acid, D-glucosaminic acid, D-glucuronic acid, $\gamma$-hydroxybutiric acid, p-hydroxyphenylacetic acid, itaconic acid, malonic acid, inosine, uridine, thymidine, phenylethylamine, $\mathrm{D}, \mathrm{L},-\alpha-$ glycerophosphate and glucose-1-phosphate

\begin{tabular}{|c|c|c|c|c|c|c|c|c|c|}
\hline Test & $\begin{array}{c}\text { NCIMB } \\
11148\end{array}$ & $\begin{array}{l}\text { ATCC } \\
13260\end{array}$ & $00 / 50 / 6670$ & 4115 & $03 / 50 / 822$ & 03/40/5697 & 03/09/159 & $02 / 50 / 2284 a$ & $02 / 50 / 2284 b$ \\
\hline Dextrin & - & - & + & - & - & - & - & - & - \\
\hline Glycogen & - & - & + & - & - & - & - & - & - \\
\hline $\begin{array}{l}\text { N-acetyl- } \\
\text { D-glucosamine }\end{array}$ & + & + & + & - & + & + & + & + & + \\
\hline Adonitol & - & + & - & - & + & - & - & - & - \\
\hline Cellobiose & - & - & + & - & - & - & - & - & - \\
\hline l-erythritol & - & + & - & - & + & + & - & - & - \\
\hline$\alpha$-D-glucose & - & - & + & - & + & - & - & - & - \\
\hline m-inositol & + & + & + & - & + & + & + & + & + \\
\hline Maltose & - & - & + & - & - & - & - & - & - \\
\hline D-mannose & - & - & + & - & - & - & - & - & - \\
\hline Methyl pyruvate & - & - & - & - & + & + & + & - & - \\
\hline Citric acid & + & + & + & - & - & - & - & + & + \\
\hline $\begin{array}{l}\alpha \text {-hydroxybutyric } \\
\text { acid }\end{array}$ & + & + & + & - & + & + & + & + & - \\
\hline$\alpha$-keto glucaric acid & - & - & - & - & - & + & - & - & - \\
\hline$\alpha$-keto butyric acid & + & + & + & - & + & + & + & + & - \\
\hline$\alpha$-keto valeric acid & + & + & + & - & + & + & + & + & + \\
\hline D,Ll-lactic acid & + & - & + & - & + & + & + & - & + \\
\hline Alaninamide & - & - & - & - & + & - & - & - & - \\
\hline L-alanylglycine & + & + & - & - & + & + & + & + & - \\
\hline L-aspartic acid & - & - & + & - & - & + & - & - & - \\
\hline $\begin{array}{l}\text { Glycyl-L-aspartic } \\
\text { acid }\end{array}$ & - & - & + & - & - & - & - & - & - \\
\hline $\begin{array}{l}\text { Glycyl-L-glutamic } \\
\text { acid }\end{array}$ & - & - & + & - & - & + & - & - & - \\
\hline L-proline & - & + & + & + & + & + & + & + & - \\
\hline L-pyroglutamic acid & - & + & - & - & - & - & - & + & - \\
\hline L-serine & - & - & + & - & + & + & + & - & - \\
\hline L-threonine & - & - & + & - & + & + & + & - & - \\
\hline$\gamma$-amino butyric acid & - & + & + & - & + & + & + & - & - \\
\hline 2,3 butanediol & - & + & + & + & + & + & + & + & + \\
\hline $\begin{array}{l}\text { Glucose- } 6 \\
\text { phosphate }\end{array}$ & - & - & - & + & - & - & - & - & - \\
\hline
\end{tabular}

fluid of the 5 fish for which this fluid was examined. Although a distended abdomen was observed only in some individuals, all dead fish displayed gross pathological changes, including hyperaemia of the injection site, fin bases and gut. Internal findings for all individuals were a varying amount of seromucoid content in stomach, serous or serohaemorrhagic ascitic fluid and whitish, loose material covering the abdominal organs; 2 individuals displayed particularly extensive pathological changes, as shown in Fig. 2. Sparse to moderate growth of Rhodococcus erythropolis was recorded for the 2 fish which died in the group injected with vaccine alone.

\section{DISCUSSION}

Bacterial strains such as those found during the present study are difficult to speciate using the standard phenotypical techniques available in most aquatic microbiology laboratories. Rhodococcus erythropolis is rather poorly phenotypically described in the literature. As can be seen in Tables $2 \& 3$, the phenotypic profiles of type and reference strains provides evidence that $R$. erythropolis as a species is somewhat heterogeneous. Although the isolates under study also revealed several variable traits, many more traits were common to all, and we conclude therefore that Norwe- 


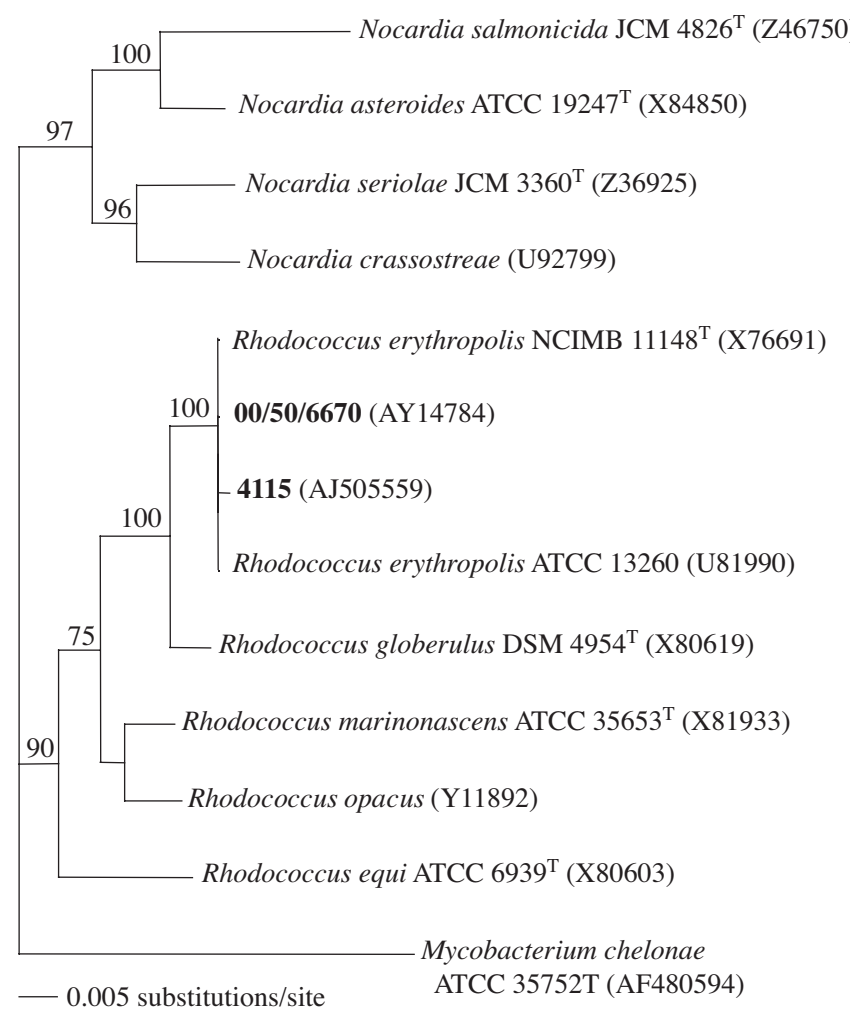

Fig. 7. Neighbour-joining phylogenetic tree constructed using 16S rDNA sequences comparing 2 isolates from present study (NVI 00/50/6670 and 4115) with reference isolates. Мycobacterium chelonae included as outgroup. Culture collection references are given where applicable. ATCC: American Type Culture Collection; NCIMB: National Collection of Industrial and Marine Bacteria; JCM: Japan Collection of Microorganisms. GenBank accession numbers in parentheses

gian Isolate 00/50/6670 and Scottish Isolate 4115, for which ribosomal sequence and ERIC-PCR data are available, belong to the species $R$. erythropolis and that the remaining Norwegian isolates with basically similar phenotypical profiles in all probability also belong to this species.

The isolation of the bacterium from all diseased individuals in all cases and the consistent finding of pathological changes associated with large numbers of Gram-positive rods morphologically similar to Rhodococcus erythropolis (as revealed by histopathological examination) strongly indicates an association between pathology and the isolated bacterium.

While we were unable to establish disease by challenge with Rhodococcus erythropolis alone, mortalities reached $100 \%$ in fish simultaneously vaccinated with oil-adjuvanted vaccines. Rhodococcus spp. are frequently used in industrial bioremediation of hydrocarbons, including mineral oils (Castorena et al. 2002), and $R$. erythropolis has been shown to be a particularily active species (Zviagintseva et al. 2001). It may be

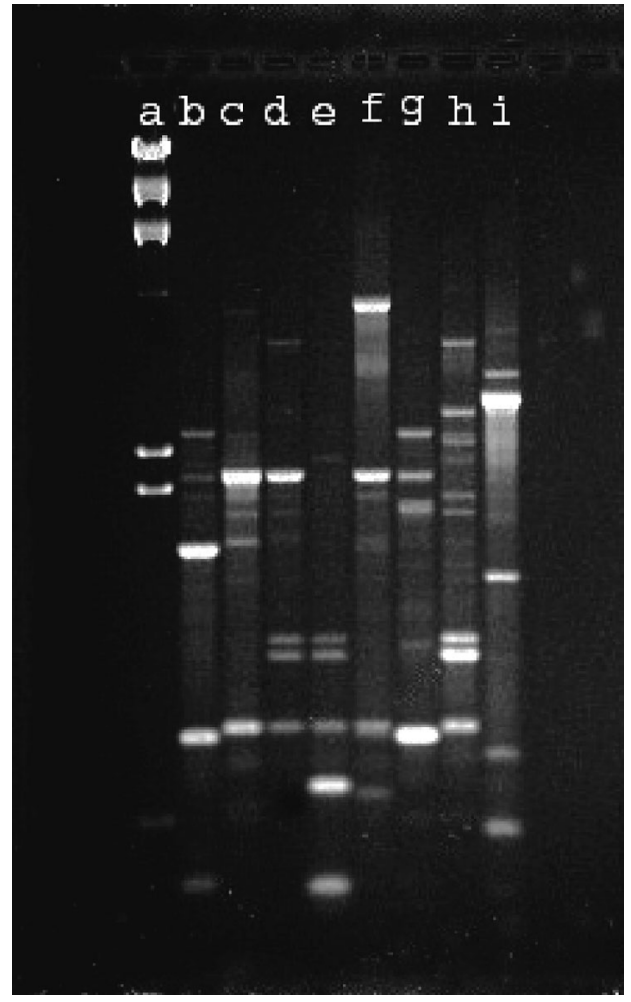

Fig. 8. Rhodococcus erythropolis. ERIC-PCR of strains isolated from diseased salmon Salmo salar. Lane a: molecular weight marker Lamda HindIII; b: ATCC 13260; C: NCIMB $11148^{\mathrm{T}}$; d: 4115 ; e: 02/05/822; f: 03/40/5697; g: 00/50/6670; h: 02/50/2284; i: 03/09/159

speculated that the oil component of oil-adjuvanted vaccines provides a source of nutrition and may also provide a degree of physical protection from the immune system of the fish. A strong association between intraperitoneal immunisation with an oilbased vaccine and infection with $R$. erythropolis is also supported by the consistent and main histopathological findings in field cases showing large numbers of bacteria and leucocytes together with vaccine-induced peritonitis. Also, 2 field cases were diagnosed within 2 to $3 \mathrm{wk}$ of vaccination. In 1 of these 2 cases the association between vaccination and infection is strong, as the nature of the outbreak (unplanned infection in a stock of experimental fish) allowed close monitoring of the course of disease. There was, however, no consistency between the time of vaccination and the detection of the infection, as in 5 cases no disease was seen until some months later, even after sea transfer (3 instances). These fish may have been infected at a later stage, but may also have been long-term asymptomatic carriers. As the preferred growth temperature for our isolates seems to be in the warmer range, i.e. above $22^{\circ} \mathrm{C}$, and growth is inhibited by the addition of $\mathrm{NaCl}$, we also believe that exposure of these fish to the 


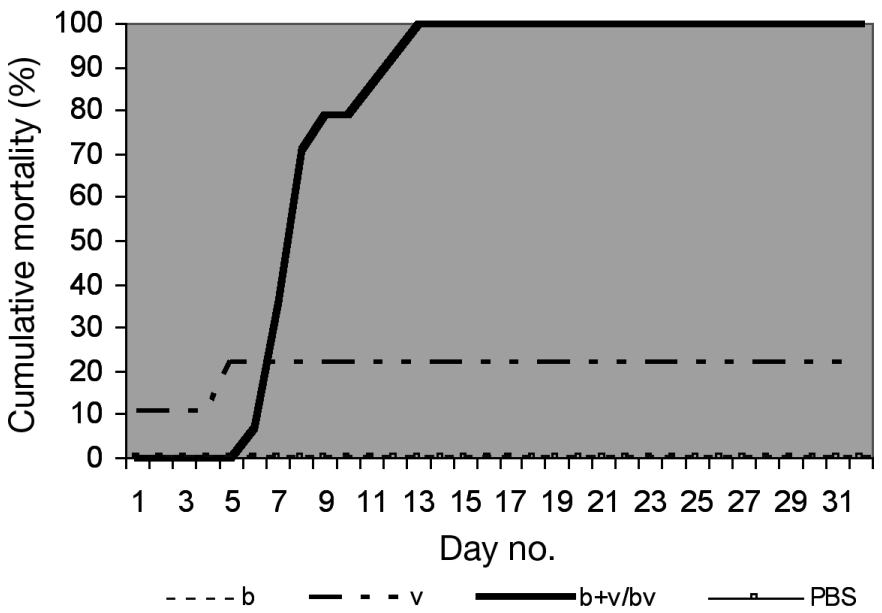

Fig. 9. Salmo salar. Infection challenge with intraperitoneally injected Rhodococcus erythropolis alone and with oiladjuvanted vaccine, showing cumulative percentage mortality in challenge groups during observation period. b: bacteria; $\mathrm{v}$ : vaccine; $\mathrm{b}+\mathrm{v}$ : bacteria and vaccine in 2 separate injections; bv: bacteria and vaccine in same injection; PBS: phosphatebuffered saline

bacterium in the freshwater phase is most likely. Evidence for transmission of the bacteria from infected fish to non-infected vaccinated fish exists. In both our third experimental infectious challenge and during a natural outbreak within a population of experimental fish, transmission to non-infected groups was identified.

The natural source of the infection is not known. Rhodococcus erythropolis is described from terrestrial (Saadoun 2002), marine (Heald et al. 2001) and freshwater (van der Wef et al. 1999) environments. We believe that the rather limited number of outbreaks seen so far indicates that the bacterium is not endemic in the salmon populations. The fish may have become infected as the result of a suboptimal hygienic environment at the time of vaccination, i.e. soil-contaminated water or contaminated needles. Questionable vaccination standards were reported for some fish groups in this study (epidemiological data not shown), but infection also occurred in fish held in a strictly controlled environment. ERIC-PCR analysis supported by serological studies indicates that while a degree of relatedness exists between several of the strains, they are genetically quite heterogeneous. Although the possibility exists that the bacteria may have been introduced to the fish via the vaccine itself, the evidence suggests that no common source of infection exists and that contamination of vaccine components during manufacture is therefore unlikely. Indeed, one would probably also have expected larger outbreaks if batches of contaminated vaccine had been the source of infection.
In farmed salmonids, 2 cases of infection by Rhodococcus spp. have previously been reported. Backman et al. (1990) describe an outbreak of panophthalmitis in farmed chinook salmon with the presence of a Rhodococcus sp. alone or together with a Mycobacterium sp. Chronic granulomatous nephritis in juvenile Atlantic salmon and the isolation of a Rhodococcus sp. was reported by Claveau (1991). Although the Rhodococcus spp. isolated in these cases clearly differed phenotypically, the description given by Claveau (1991) may suggest a relationship between that isolate and the $R$. erythropolis isolates presented here. In conclusion, although further studies are necessary to elucidate the pathogenesis of this vaccinerelated infection, it adds to the growing list of production-related 'diseases' previously described in vaccinated Atlantic salmon (Poppe \& Breck 1997, Koppang et al. 2003, 2004, 2005) and indicates the potential for further refinement of both vaccines and vaccination procedures.

We believe this is the first description of infection in fish by Rhodococcus erythropolis. It is also, to our knowledge, the first demonstration that exposure to oil-adjuvanted vaccine may predispose the vaccinated fish to infection with an otherwise harmless bacterium.

Acknowledgements. We gratefully acknowledge Harry Rudra, Marine Institute Bergen, for help with the experimental fish, Elly Soltvedt, National Veterinary Institute Bergen, for technical histological and microbiological assistance and Professor Trygve Poppe, Norwegian School of Veterinary Science, for critical reading of the manuscript.

\section{LITERATURE CITED}

Altschul SF, Madden TL, Schäffer AA, Zhang J, Zhang Z, Miller W, Lipmann DJ (1997) Gapped BLAST and PSIBLAST: a new generation of protein database search programs. Nucleic Acids Res 25:3389-3402

Austin B, Austin D (1999) Bacterial fish pathogens: diseases of farmed and wild fish. Praxis, Chichester

Backman S, Ferguson HW, Prescott JF, Wilcock BP (1990) Progressive panophthalmitis in chinook salmon, Oncorhynchus tshawytscha (Walbaum): a case report. J Fish Dis 13:345-353

Castorena G, Suarez C, Valdez I, Amador G, Fernandez L, le Borgne S (2002) Sulfur-selective desulfurization of dibenzothiophene and diesel oil by newly isolated Rhodococcus sp. strains. FEMS Microbiol Lett 215:157-161

Claveau R (1991) Néphrite granulomateuse à Rhodococcus spp. dans un élevage de saumons de l'Atlantique (Salmo salar). Méd Vet Qué 21:160-161 (in French)

Heald SC, Brandao PF, Hardicre R, Bull AT (2001) Physiology, biochemistry and taxonomy of deep-sea nitrite metabolising Rhodococcus strains. Antonie Leeuwenhoek 80: 169-183

Koppang EO, Bjerkås E, Bjerkås I, Sveier H, Hordvik I (2003) Vaccination induces major histocompatibility complex class II expression in the Atlantic salmon eye. Scand J Immunol 58:9-14 
Koppang EO, Haugarvoll E, Hordvik I, Poppe TT, Bjerkås I (2004) Granulomatous uveitis associated with vaccination in the Atlantic salmon. Vet Pathol 41:122-130

Koppang EO, Haugarvoll E, Hordvik I, Aune L, Poppe TT (2005) Vaccine associated granulomatous inflammation and melanin accumulation in Atlantic salmon, Salmo salar L., white muscle. J Fish Dis 28:13-22

Larsen JL, Pedersen K, Dalsgaard I (1994) Vibrio anguillarum serovars associated with vibriosis in fish. J Fish Dis 17: 259-267

Olsen AB, Colquhoun DJ, Wangel C, Nilsen HK (2001) Mortality in Atlantic salmon (Salmo salar L.) smolt associated with infection by Rhodococcus erythropolis. In: Abstract book European Association of Fish Pathologists Tenth International Conference Disease of Fish and Shellfish, Trinity College, Dublin, p 95

Poppe TT, Breck O (1997) Pathology of Atlantic salmon Salmo salar intraperitoneally immunized with oil-adjuvanted vaccine. A case report. Dis Aquat Org 29:219-226

Saadoun I (2002) Isolation and characterisation of bacteria from crude petroleum oil contaminated soil and their potential to degrade diesel fuel. J Basic Microbiol 42:420-428

Editorial responsibility: David Bruno,

Aberdeen, UK
Swofford DL (2000) PAUP* phylogenetic analysis using parsimony and other methods (Software). Sinauer Associates, Sunderland, MA

Thompson JD, Higgins DG, Gibson TJ (1994) CLUSTAL W: improving the sensitivity of progressive multiple sequence alignment through sequence weighting, position specific gap penalties and weight matrix choice. Nucleic Acids Res 22:4673-4680

van der Werf MJ, Swarts HJ, de Bont JA (1999) Rhodococcus erythropolis DCL14 contains a novel degradation pathway for limonene. Appl Environ Microbiol 65:2092-2102

Ventura M, Zink R (2002) Specific identification and molecular typing analysis of Lactobacillus johnsonii by using PCR-based methods and pulsed-field gel electrophoresis. FEMS Microbiol Lett 217:141-154

Weisburg WG, Barns SM, Pelletier DA, Lane DJ (1991) 16S ribosomal DNA amplification for phylogenetic study. J Bacteriol 173:697-703

Zviagintseva IS, Surovtseva EG, Poglazova MN, Ivoilov VS, Beliaev SS (2001) Degradation of machine oil by nocardioform bacteria. Mikrobiologiya 70:321-328 (in Russian)

Submitted: October 6, 2005; Accepted: March 29, 2006

Proofs received from author(s): August 25, 2006 